ISSN 1392-3196 / e-ISSN 2335-8947

Zemdirbyste-Agriculture, vol. 102, No. 3 (2015), p. 257-264

DOI 10.13080/z-a.2015.102.033

\title{
The fluctuation of calcium and magnesium concentrations in the floodwater in the Nemunas and Minija lowlands
}

\author{
Kazimieras KATUTIS ${ }^{1}$, Aurelija RUDZIANSKAITE ${ }^{2}$ \\ ${ }^{1}$ Vėžaičiai Branch, Lithuanian Research Centre for Agriculture and Forestry \\ Gargždų 29, Vėžaičiai, Klaipėda distr., Lithuania \\ E-mail: kkatutis@yahoo.co.uk \\ ${ }^{2}$ Institute of Water Resources Engineering, Aleksandras Stulginskis University \\ Universiteto 10, Akademija, Kaunas distr., Lithuania \\ E-mail: aurelija.rudzianskaite@asu.lt
}

\begin{abstract}
Calcium $(\mathrm{Ca})$ and magnesium $(\mathrm{Mg})$ are vital elements for the neutralization of soil or water acidity, which is associated with the activity of biota, mobility of heavy metals, phosphorus and other important elements. The current research was aimed to estimate the trends in the fluctuation of calcium and magnesium ions in the floodwater using traditional experimental methods. The studies were carried out during the 1987-2010 period in the Nemunas lowland (upper (Rambynas-Plaškiai) and lower (Girininkai-Smalkai) zones) and in the Minija lowland. In the floodwater of both rivers, the concentration of $\mathrm{Ca}^{2+}$ was up to three times as high as the mean annual concentration in the river and that of $\mathrm{Mg}^{2+}$ concentration by up to 1.6 times higher than in the river. A trend towards increasing of these ions concentration in the floodwater was established. In the upper zone of the Nemunas lowland the concentrations of $\mathrm{Ca}^{2+}\left(159-248 \mathrm{mg} \mathrm{l}^{-1}\right)$ and $\mathrm{Mg}^{2+}\left(14.3-29.3 \mathrm{mg} \mathrm{l}^{-1}\right)$ in floodwater were something higher than those in the lower zone $-152-240$ and $13.5-25.3 \mathrm{mg} \mathrm{l}^{-1}$, respectively. These differences were significant: $\mathrm{Ca}^{2+}-t_{\text {act. }}$ $=1.75>t_{0.05}=1.65$ and $\mathrm{Mg}^{2+}-t_{\text {act. }}=3.25>t_{0.05}=1.65$. The concentration of these ions with increasing distance from the riverbed decreased and was the lowest in the pre-land part of the floodplain. The strongest correlation between $\mathrm{Ca}^{2+}\left(r^{2}=0.82, t_{\text {act. }}=7.87>t_{0.05}=1.75\right)$ and $\mathrm{Mg}^{2+}\left(r^{2}=0.43, t_{\text {act. }}=3.25>t_{0.05}=1.75\right)$ concentrations in the water and soil was determined in the lowest parts of the relief $(<0 \mathrm{~m})$, when the floodwater was at more than $1 \mathrm{~km}$ distance from the riverbed. The concentrations of the tested ions at the beginning of flood reflect the amount of substances carried from the catchment areas into the rivers. The quality of the water flowing through the valley depended on the relief height, flow velocities and distribution and soil properties.
\end{abstract}

Key words: calcium, floodplain, floodwater, magnesium, meadows.

\section{Introduction}

Due to the contaminants carried by the rivers, the Curonian Lagoon is characterised by a high degree of eutrophication, which is evidenced by the high concentrations of dissolved nitrogen and phosphorus in the winter period and intensive algal blooms during the warm period of the year (Environmental Protection Agency, 2010). More than $73 \%$ of Lithuania's territory belongs to the Nemunas River basin. The water flowing from this territory into the Baltic Sea brings the largest amount of pollutants formed in Lithuania. It was estimated that with the flow of the Nemunas and other rivers the following contents of pollution can be deposited in the Curonian Lagoon annually: about 58129 t of organic matter (according to biochemical oxygen demand, $\mathrm{BOD}_{7}$ ), $905 \mathrm{t}$ of ammonium nitrogen, $23441 \mathrm{t}$ of nitrate nitrogen, $1751 \mathrm{t}$ of total phosphorus (Environmental Protection Agency, 2010). The river's pollution load each year varies depending on the river run-off volume. The Nemunas flooded meadows are a natural clarifier for pollutants carried by the flood water from the upper reaches and therefore pollution of the Lagoon is reduced. The water carried by the flood into the valley becomes clearer by leaving sediment layer on the floodplain surface (Vaikasas, 2009; Adomaitis, Vaikasas, 2011). The deposition of biogenic elements is utilised by the grasses during the growing season. Moreover, the elements that get into the soil can stimulate exchange between the mobile and total forms. The ions of phosphates or metals bind to clay particles or insoluble organic compounds, while organic compounds bind to calcium ions (Tumas, 2003; Katutis, 2007). Not only absorption of various ions but also their leaching occurs in the soil exposed to flooding. During the flood period when infiltration increases, the content of sulphates and iron increases, while $\mathrm{pH}$ and alkalinity decrease (Miotliński et al., 2012). In the pores of the flooded soil the level of oxygen declines, the chemical composition of water changes and the soil is enriched by various nutrients. A reduction in oxygen content can trigger the formation of anaerobic conditions, which cause denitrification, methanogenesis, 
reduction of manganese, iron, and sulphate, resulting in a lowering of the soil redox potential (Beumer et al., 2007). Alteration in $\mathrm{pH}$ and redox reactions will change the bioavailability of nutrients in the soil (Lynch et al., 2014). $\mathrm{pH}$, ammonium and phosphate levels increase, when the soils become anaerobic (Beumer et al., 2007; Loeb et al., 2007). When $\mathrm{pH}$ drops below 4.5 , almost all carbonates are dissolved and adsorption to Fe oxide is the dominant mechanism (Lucassen et al., 2002). In floodplain soils containing high amounts of organic matter, sulphate is known to increase the mobilization of phosphate (Loeb et al., 2007; Banach et al., 2009). In the inundated soils $\mathrm{CO}_{2}$, originating from decomposition of organic matter, could be trapped in the soil and could cause dissolution of $\mathrm{CaCO}_{3}$ and $\mathrm{MgCO}_{3}$, which could be present in the soil in small amounts, notwithstanding the low initial $\mathrm{pH}$ of the soil (Loeb et al., 2008). If the river water is low in bicarbonate content, the $\mathrm{pH}$ value of the water is reduced and because of which aluminium and heavy metals may become soluble and toxic. The level of phosphorus also increases in such conditions (Tumas, 2003). Calcareous substances alter the mobility of some biogenic elements and heavy metals and their accumulation in the soil, reduce organic carbon content and increase the activity of biota (Marcinkonis et al., 2011). Organic carbon amount in the soil positively correlates with phosphorus amount. With increasing carbon to total phosphorus ratio in the soil, mobilization of phosphorus occurs in the soil phosphorus is lost from the soil, and when mineralization processes prevail (decreasing C:P ratio) - phosphorus is accumulated in the soil (Jokubauskaitè et al., 2014). The adsorption of phosphorus is determined not only by the soil organic carbon but also by $\mathrm{pH}$, calcium, magnesium, iron, aluminium, and soil texture (Moazed et al., 2010). Excess phosphorus causes eutrophication in the surface waters. Calcium and magnesium are very important elements for the neutralization of soil and water acidity, which is associated with the activity of biota and mobility of heavy metals, phosphorus and other relevant elements.

In Lithuania, the soils used for agricultural production have hardly been limed during the past two decades, which has resulted in their gradual acidification.
At present, about $18.7 \%$ of Lithuanian agricultural land is acidic and about 1 million ha are at risk of chemical degradation by acidification (Marcinkonis et al., 2011).

While addressing the current environmental challenges on the global level, the fundamental knowledge of the regularities of water chemical composition and quality is focused on several major directions. However, the priority is given to regional studies, which are based mainly on complex research into hydrophysical and hydrological processes. This is particularly important while analysing the effects of climate change on these processes as well as on the dynamics of water chemical composition and quality.

The current study was designed to assess the trends of variation of calcium and magnesium ions in the floodwater in the Nemunas and Minija lowlands using traditional experimental methods.

The findings presented in this study are relevant to the experts in hydrology, water management, water ecology, environmental science and protection while addressing complex diagnostic and forecasting challenges. Each longer or shorter period (fragment) describes the state of the geo-system and shows the relevance of its indicators.

\section{Materials and methods}

Study area. The quality of floodwater was monitored during the 1987-2010 period in the Nemunas and Minija lowlands. The study area was divided into three parts (Fig. 1): upper zone (Rambynas-Plaškiai) - during the flood period the Nemunas River behind Rambynas hill outflows into the valley and returns into the riverbed at Plaškiai (1-3 cross sections, further on sections); lower zone - Girininkai-Smalkai zone (4-7 sections) - during the flood period the Nemunas River outflows behind Girininkai village into the valley for the second time and via the Krokai meadow flows into the Curonian Lagoon; the valley of the Minija-Tenenis Rivers (8-10 sections) is composed of the flooded meadows of the Alka polder (beginning at Lankupiai) and through the flooded summer polder of the Minija into the Curonian Lagoon.

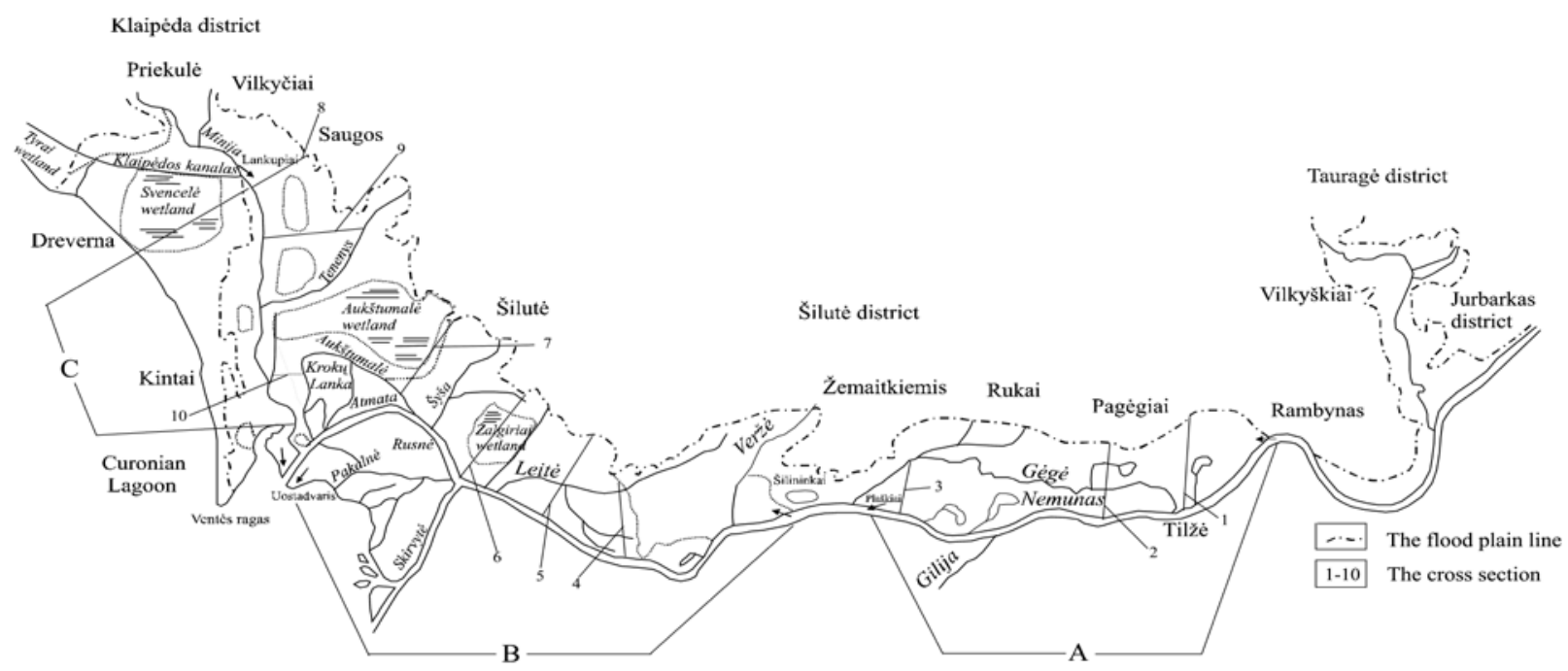

Nemunas lowland: Rambynas-Plaškiai zone (A): 1 - Nemunas-Mikytai, 2 - Nemunas-Plaušvarai, 3 - Nemunas-Plaškiai; Girininkai-Smalkai zone (B): 4 - Nemunas-Paleičiai, 5 - Nemunas-Sausgalviai, 6 - Atmata-Šliažai, 7 - Aukštumalè-Ššgiriai; Minija lowland (C): 8 - Minija-Sakūtèliai, 9 - Minija-Alka, 10 - Minija-Krokų Lanka

Figure 1. The scheme of sampling places in the Nemunas and Minija lowlands 
In the sections, water and soil samples were taken in 5 places: 1 - pre-riverbed, $2-4$ - central and 5 pre-land zone (Table 1). The soil surface altitude near the beginning of the Nemunas lowland, Rambynas-Plaškiai zone, was higher $(-2-+8 \mathrm{~m})$ than near the river mouth, Girininkai-Smalkai zone $(-4-+3 \mathrm{~m})$ or in the Minija lowland $(-4-+2 \mathrm{~m})$.

Table 1. The characteristic of the floodwater test places

\begin{tabular}{|c|c|c|c|c|c|c|}
\hline \multirow{2}{*}{ Cross section } & \multirow{2}{*}{ Characteristic } & \multicolumn{5}{|c|}{ Water test place } \\
\hline & & 1 & 2 & 3 & 4 & 5 \\
\hline & & \multicolumn{5}{|c|}{$\begin{array}{l}\text { Nemunas lowland } \\
\text { mbynas-Plaškiai zone }\end{array}$} \\
\hline \multirow{6}{*}{$\begin{array}{l}\text { 1. Nemunas-Mikytai, distance } \\
\text { from the river mouth } 60 \mathrm{~km} \\
\text { 2. Nemunas-Plaušvarai, distance } \\
\text { from the river mouth } 55 \mathrm{~km} \\
\text { 3. Nemunas-Plaškiai, distance } \\
\text { from the river mouth } 43 \mathrm{~km}\end{array}$} & Distance from the river $\mathrm{m}$ & 685 & 1800 & 2600 & 3350 & 4200 \\
\hline & Soil surface altitude m & 2.0 & 4.0 & 3.0 & 3.5 & 8.0 \\
\hline & Distance from the river $m$ & 850 & 1100 & 2000 & 3090 & 3500 \\
\hline & Soil surface altitude m & 1.0 & 3.0 & 2.0 & 1.0 & 4.5 \\
\hline & Distance from the river $\mathrm{m}$ & 720 & 1260 & 2260 & 2785 & 3250 \\
\hline & Soil surface altitude $\mathrm{m}$ & 1.0 & 1.0 & 0.0 & -2.0 & 0.0 \\
\hline & & \multicolumn{5}{|c|}{ Girininkai-Smalkai zone (B) } \\
\hline \multirow{2}{*}{$\begin{array}{l}\text { 4. Nemunas-Paleičiai, distance } \\
\text { from the river mouth } 24 \mathrm{~km}\end{array}$} & Distance from the river $\mathrm{m}$ & 665 & 1250 & 2000 & 2700 & 3000 \\
\hline & Soil surface altitude m & 1.0 & 2.0 & 3.0 & 0.0 & -1.0 \\
\hline \multirow{6}{*}{$\begin{array}{l}\text { 5. Nemunas-Sausgalviai, distance } \\
\text { from the river mouth } 14 \mathrm{~km} \\
\text { 6. Atmata-Šliažai, distance } \\
\text { from the river mouth } 10 \mathrm{~km} \\
\text { 7. Aukštumalè-Šyšgiriai, distance } \\
\text { from the river mouth } 4 \mathrm{~km}\end{array}$} & Distance from the river $\mathrm{m}$ & 825 & 1750 & 3000 & 3800 & 6000 \\
\hline & Soil surface altitude m & 1.0 & 0.0 & -1.0 & 0.0 & 2.0 \\
\hline & Distance from the river $m$ & 720 & 2300 & 3500 & 5400 & 6100 \\
\hline & Soil surface altitude m & 0.0 & -4.0 & -4.0 & -4.0 & 0.5 \\
\hline & Distance from the river $\mathrm{m}$ & 90 & 720 & 1500 & 2370 & 3000 \\
\hline & Soil surface altitude $\mathrm{m}$ & -4.0 & -2.0 & -3.0 & 3.0 & 0.5 \\
\hline & & \multicolumn{5}{|c|}{ Minija lowland (C) } \\
\hline \multirow{6}{*}{$\begin{array}{l}\text { 8. Minija-Sakūtėliai, distance } \\
\text { from the river mouth } 13.5 \mathrm{~km} \\
\text { 9. Minija-Alka, distance } \\
\text { from the river mouth } 9 \mathrm{~km} \\
10 . \text { Minija-Krokų Lanka, distance } \\
\text { from the river mouth } 3 \mathrm{~km}\end{array}$} & Distance from the river $m$ & 150 & 900 & 1500 & 1600 & 2000 \\
\hline & Soil surface altitude m & 0.0 & 1.0 & -1.0 & 0.0 & 2.0 \\
\hline & Distance from the river $\mathrm{m}$ & 250 & 1200 & 3050 & 4100 & 4400 \\
\hline & Soil surface altitude m & 0.0 & -4.0 & -1.0 & -3.0 & 0.1 \\
\hline & Distance from the river $\mathrm{m}$ & 80 & 1000 & 1700 & 1850 & 2250 \\
\hline & Soil surface altitude $\mathrm{m}$ & -2.0 & -3.0 & -4.0 & -4.0 & -3.0 \\
\hline
\end{tabular}

Sampling. Water samples were taken in four replications during the flood period, when the water height was lower than the height of the protective dikes and the water did not flow into the meadows. Soil samples were taken from the $0-20 \mathrm{~cm}$ depth in four replications. Soil texture was determined by the pipette method according to FAO. Calcium $(\mathrm{Ca})$ and magnesium $(\mathrm{Mg})$ in water was measured by the EDTA titrimetric method (ISO 6058:1984), in the soil by the A-L method, according to Egnér et al. (1960). Water and soil analyses were conducted at the laboratory of Vèžaičiai Branch of Lithuanian Research Centre for Agriculture and Forestry. Soil background. The properties of Fluvisols are formed by the two major factors: mineral sediments brought by the flood and organic matter conserved by high groundwater (Gipiškis et al., 2007). The soils of the Nemunas lowland most often were HapliCalcaric Fluvisol and those of the Minija lowland were Endohypergleyi-Dystric Fluvisol and Terri-Fibric Histosol (Table 2).

Table 2. The soil group in floodwater test places

\begin{tabular}{|c|c|c|c|c|c|}
\hline \multirow{2}{*}{ Cross section } & \multicolumn{5}{|c|}{ Water test place } \\
\hline & 1 & 2 & 3 & 4 & 5 \\
\hline 1 & $F L c-a$ & FLc-ha & $F L e-g \ln -w$ & $F L e-g l n-h$ & $F L e-o$ \\
\hline 2 & $F L c-a$ & FLc-ha & FLe-gln-w & $F L e-g \ln -h$ & FLe-o \\
\hline 3 & $F L c-a$ & $F L c-h a$ & FLe-gln-w & $F L e-g \ln -h$ & $F L d-p$ \\
\hline 4 & $F L c-a$ & $F L c-h a$ & FLm-hib & FLu-hib & $F L d-p$ \\
\hline 5 & $F L c-a$ & $F L c-h a$ & FLm-ha & FLu-hib & $F L d-g \ln -w$ \\
\hline 6 & $F L c-a$ & $F L c-h a$ & FLm-hib & FLm-hib & $F L d-g \ln -h$ \\
\hline 7 & $F L c-h a$ & $F L c-g \ln -h$ & FLu-hib & FLu-hib & $F L c-h a$ \\
\hline 8 & $F L c-a$ & $F L c-g \ln -h$ & $F L d-g \ln -h$ & $F L d-g \ln -h$ & $F L d-p$ \\
\hline 9 & FLc-ha & FLu-hib & $H S s-d$ & $H S f-s$ & $H S f-s$ \\
\hline 10 & FLu-hib & $H S s-d$ & $H S s-d$ & $H S f-s$ & $H S f-s$ \\
\hline
\end{tabular}

FLe-o - Orthieutric Fluvisol, FLe-gln-w - Endohypogleyi-Eutric Fluvisol, FLe-gln-h - Endohypergleyi-Eutric Fluvisol, FLuhib - Thaptohisti-Umbric Fluvisol, FLc-gln-h - Endohypergleyi-Calcaric Fluvisol, FLc-ha - Hapli-Calcaric Fluvisol, FLc-a Areni-Calcaric Fluvisol, FLd-p - Epidystric Fluvisol, FLd-gln-w - Endohypogleyi-Dystric Fluvisol, FLd-gln-h - EndohypergleyiDystric Fluvisol, FLm-ha - Hapli-Mollic Fluvisol, FLm-hib - Thaptohisti-Mollic Fluvisol, HSf-s - Terri-Fibric Histosol, HSs-d - Bathiterric Histosol 
In the lowlands of both rivers the soils had the lowest content (5.22-22.12\%) of clay particles in the preriverbed part and the highest content (14.56-48.74\%) in the pre-land part (Fig. 2). With the relief altitude going down and flood period becoming longer the content of physical sand regularly decreases and that of physical clay increases.

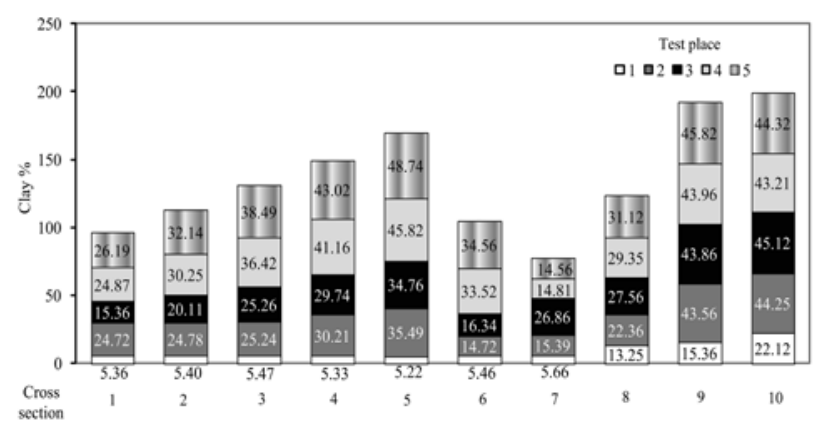

Figure 2. The content of clay particles in the soil in the floodwater test places

In mineral soils, with increasing organic matter amount, the content of calcium declines and the weight of hard-to-dissolve fractions of clay humates increases. In Fluvisol the fraction of calcium humate is very low (Gipiškis et al., 2007). The average mobile calcium content when $\mathrm{pH}$ is higher than 6.0 , in various sandy loam soils of Lithuania varies from 1880 to $3390 \mathrm{mg} \mathrm{kg}^{-1}$, in loamy soils - from 1960 to $3180 \mathrm{mg} \mathrm{kg}^{-1}$, and in peat is about $5960 \mathrm{mg} \mathrm{kg}^{-1}$ (Agrochemical properties..., 1998). In the Fluvisol of the Nemunas and Minija lowlands, the amount of mobile Ca was higher, and in the peat soils of the Minija lowland it was lower than the national average (Fig. 3).

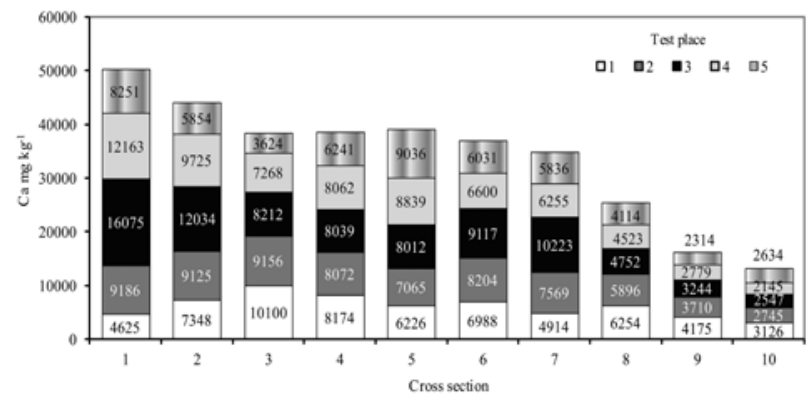

Figure 3. The amount of mobile $\mathrm{Ca}$ in the soil in the floodwater test places

The soils high in magnesium content are considered to be those whose $\mathrm{pH}$ is above 6.1 and which contain more than $300 \mathrm{mg} \mathrm{kg}^{-1}$ of mobile magnesium (Agrochemical properties..., 1998). In the studied areas of the lowland the soils were high in magnesium (Fig. 4). The highest Mg contents (2494-3980 mg kg-1) were determined in the pre-riverbed part of the upper zone of the Nemunas lowland.

The highest $\mathrm{Ca}\left(3624-16075 \mathrm{mg} \mathrm{kg}^{-1}\right)$ and $\mathrm{Mg}$ (647-3980 $\mathrm{mg} \mathrm{kg}^{-1}$ ) amounts in the soil were in the upper zone of the Nemunas lowland (1-3 sections), lower contents 4914-10223 and 978-1869 mg kg-1, respectively were in the lower zone (4-7 sections), and the lowest amounts in the Minija lowland - 2145-6254 and $280-612 \mathrm{mg} \mathrm{kg}^{-1}$, respectively.

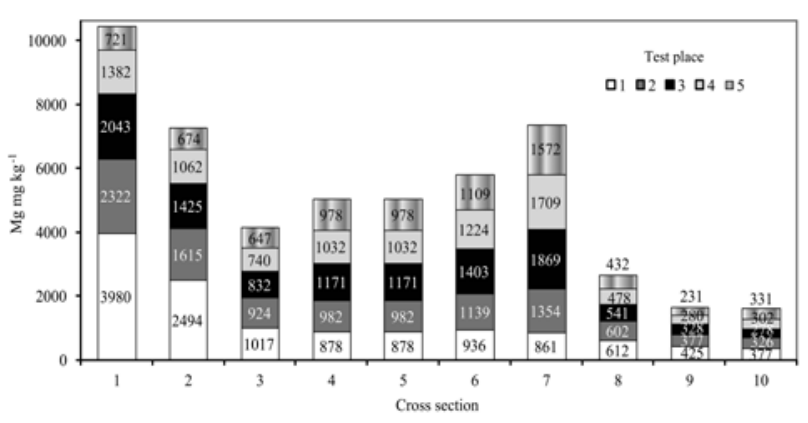

Figure 4. The amount of mobile $\mathrm{Mg}$ in the soil in the floodwater test places

Meteorological conditions. Meteorological conditions were described based on the data from the Šilute Hydrometeorological Station. Dry (probability $>95 \%$ ) hydrologic years were 1995-1996 (precipitation amount 571 mm) and 2005-2006 (579 mm), characterised by high precipitation amount (probability $>5 \%$ ) - 19891990 (961 mm) and 2006-2007 (1092 mm) (Fig. 5). The lowest air temperature $\left(5.5^{\circ} \mathrm{C}\right)$ was recorded in $1995-$ 1996 hydrologic year, the highest $\left(9.0^{\circ} \mathrm{C}\right)-$ in $2006-$ 2007. The average air temperature of the hydrologic year during the study period was $7.7^{\circ} \mathrm{C}$ and amount of precipitation $-779 \mathrm{~mm}$.

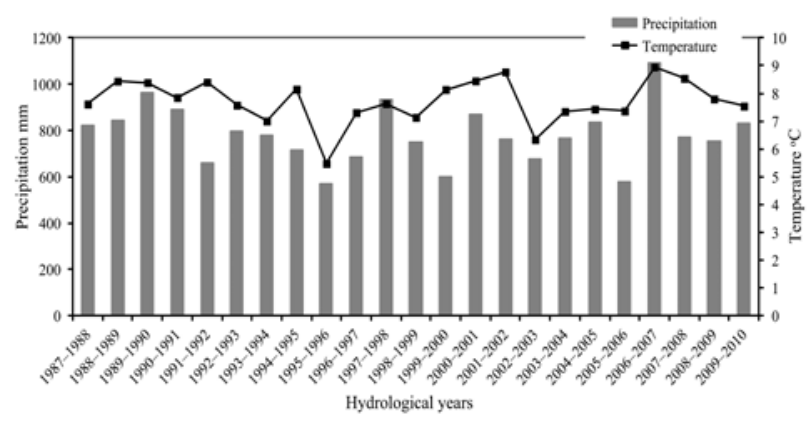

Figure 5. Precipitation and average air temperature in the hidrological years

During the study period, the flood started in January 8 times (1989, 1990, 1991, 1992, 2002, 2006, 2007 and 2008), in February 5 times $(1995,1997,2000$, 2004 and 2010), in March 8 times (1993, 1994, 1998, 1999, 2001, 2003, 2005 and 2009), and in April 3 times (1987, 1988 and 1996).

Floods occurring during the winter period have become increasingly frequent, and in the spring period relatively small and shorter water overflows take place (Adomaitis, Vaikasas, 2011). The principal criterion of flood is water height in the riverbed when flooding of delta begins. When the height of flood water corresponds to $50 \%$ probability, up to $400 \mathrm{~km}^{2}$ are flooded and the average depth of the flood water layer is about $1.8 \mathrm{~m}$ (Katutis, 2007). During the study period, the maximum flood water height variation corresponded to $17-99 \%$ probability, and the flood lasted for from 15 to 81 days (long-term average - 33 days). During the flood, the Nemunas lowland in the Rambynas-Plaškiai zone is flooded up to 3-4 m, and in Rusne-Smalkai zone up to $1.5-2.0 \mathrm{~m}$ water layer. During spring floods, lower places of the valley are flooded for on average 52-58 days, medium places for 26-33 days, and higher places for 17-21 days. 
Statistical analysis. Differences between water test places were assessed by univariate $A N O V A$. Regressioncorrelation analysis was performed in order to determine the relations among ion concentration, water level, soil properties results. The relative importance of factors and interactions were estimated using Student test $(t)$ and Fisher test $(F)$. Sample variance is expressed as mean, standard error (SE) and standard deviation (SD). Significant differences was accepted at confidence level $\alpha \leq 0.05$. All statistics were calculated with Microsoft Excel.

\section{Results and discussion}

In the water of Lithuanian rivers, the ions of hydrocarbonates, calcium and manganese account for approximately $85 \%$ of the total dissolved substances. The content of these ions is determined by the carbonate sediments. The highest content of carbonate materials is found in moraine loam, and the lowest content in glacial lacustrine and fluvioglacial sand. The least (approx. $100 \mathrm{mg} \mathrm{l}^{-1}$ ) water mineralization and the lowest concentration of hydrocarbonate, calcium and magnesium ions is characteristic of the streams that are fed by the water flowing from peat bogs (Tumas, 2003). The highest concentration of dissolved mineral matter is determined in the water of the Nemunas; lesser concentration is found in the Jüra and the least concentration in the Minija (Gipiškis, 2000). During the 2001-2009 period, the average annual concentration of $\mathrm{Ca}^{2+}$ in the Nemunas water below Smalininkai was $65.5-78.3 \mathrm{mg} \mathrm{l}^{-1}$ and that of $\mathrm{Mg}^{2+}-9.5-24.5 \mathrm{mg} \mathrm{l}^{-1}$, in the Minija water below Gargždai - 65.0-77.5 and 7.3-15.8 $\mathrm{mg} \mathrm{l}^{-1}$, respectively (Environmental Protection Agency, 2001-2009). During the study period, the concentration of $\mathrm{Ca}^{2+}$ ions in the Nemunas floodwater was established to be 157-239 and that of $\mathrm{Mg}^{2+}-14.3-24.1 \mathrm{mg} \mathrm{l}^{-1}$, in the Minija floodwater - 133-203 and 11.6-19.5 $\mathrm{mg} \mathrm{l}^{-1}$, respectively (Fig. 6).

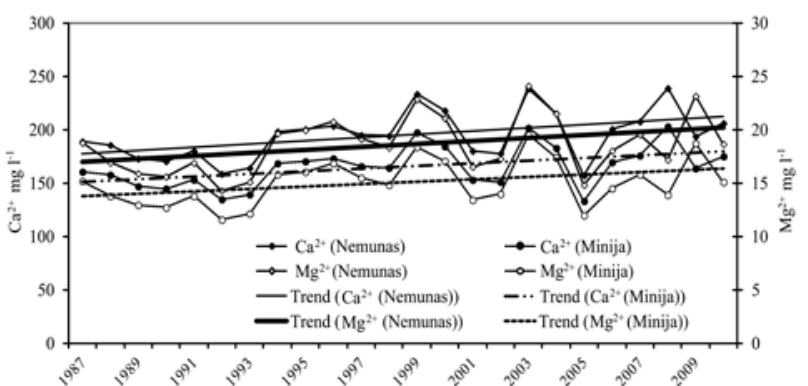

Figure 6. The change of $\mathrm{Ca}^{2+}$ and $\mathrm{Mg}^{2+}$ ion concentration in floodwater of the Nemunas and Minija lowlands

In the floodwater of both rivers $\mathrm{Ca}^{2+}$ concentration was three times as high as the average annual concentration in the river, the concentration of $\mathrm{Mg}^{2+}$ ions differed less - up to 1.6 times. This was determined by the contents of these ions carried by the greater run-off from the rivers' catchment area. In the Nemunas floodwater the concentration of $\mathrm{Ca}^{2+}$ and $\mathrm{Mg}^{2+}$ was by up to $18 \%$ and up to $24 \%$ higher than in the Minija floodwater. Research evidence suggests that during the flood period the Nemunas water is $31 \%$ more contaminated than that of the Minija (Katutis, 2007).

The concentration of calcium and magnesium ions in floodwater showed similar trends of variation. The variation of floodwater level in the Nemunas lowland determined $41 \%$ variation $\left(r^{2}=0.41, t_{\text {act. }}=3.79>t_{0.05}=\right.$ $1.71)$ of $\mathrm{Ca}$ and $42 \%$ variation $\left(r^{2}=0.42, t_{\text {act. }}=3.88>\right.$ $\left.t_{0.05}=1.71\right)$ of $\mathrm{Mg}$ concentration, in the Minija lowland $-41 \%\left(r^{2}=0.41, t_{\text {act. }}=3.81>t_{0.05}=1.71\right)$ and $42 \%$ $\left(r^{2}=0.42, t_{\text {act. }}=3.88>t_{0.05}=1.71\right)$, respectively. With increasing floodwater level, the concentrations of $\mathrm{Ca}$ and $\mathrm{Mg}$ increased. The higher the floodwater, the more sediments it contains (Katutis, 2007). Various factors can influence the increase or decrease of sediment deposition, e.g., the increase of water discharge flowing through the river valley (Rimkus, Vaikasas, 2010). The pulsing of river discharge is considered to be a major driving force that determines the degree of connectivity, the exchange of matter and the processing of organic matter and nutrients across river-floodplain gradients (Schulz-Zunkel et al., 2013).

For all study areas (1-10 sections) the average trend of chronological sequence of $\mathrm{Ca}^{2+}$ and $\mathrm{Mg}^{2+}$ concentration is positive, i.e. the quantity of these ions increases in floodwater. When the study findings were analysed at four years' intervals it was estimated that during the last period the $\mathrm{Ca}^{2+}$ concentration in the lowland of the Nemunas was 1.18 times higher and that of $\mathrm{Mg}^{2+}$ by 1.16 times higher than during the first period, in the lowland of the Minija - by 1.17 and 1.16 times, respectively. This trend may be associated with winter floods becoming more frequent. A marked increase in $\mathrm{Ca}^{2+}\left(208-239 \mathrm{mg} \mathrm{l}^{-1}\right)$ and $\mathrm{Mg}^{2+}\left(17.2-19.6 \mathrm{mg} \mathrm{l}^{-1}\right)$ concentration occurred when flood began in January in 2007 and 2008, while in $1990, \mathrm{Ca}^{2+}$ concentration in floodwater in January was $170 \mathrm{mg} \mathrm{l}^{-1}, \mathrm{Mg}^{2+}-15.6 \mathrm{mg} \mathrm{l}^{-1}$ and in $1992-159$ and $14.3 \mathrm{mg} \mathrm{l}^{-1}$, respectively. Buffam et al. (2007) suggest that the variation of $\mathrm{pH}$ in floodwater is influenced by the snow melt water. In the territory of Lithuania, the duration of snow cover has decreased by 20 days during the 1961-2010 period (Rimkus et al., 2014). In 1988-2009, the average winter temperature was $-2.9^{\circ} \mathrm{C}$, i.e. by $1.6^{\circ}$ higher and the winter run-off of the Nemunas was by $14.2 \%$ higher than the long-term mean (Jablonskis, 2012).

In the upper zone (1-3 sections) of the Nemunas lowland the concentration of $\mathrm{Ca}$ 159-248 $\mathrm{mg} \mathrm{l}^{-1}$ (on

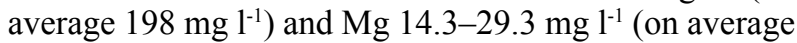
$\left.20.3 \mathrm{mg} \mathrm{l}^{-1}\right)$ in floodwater was higher than in the lower zone (4-7 sections) - 152-240 $\mathrm{mg} \mathrm{l}^{-1}\left(192 \mathrm{mg} \mathrm{l}^{-1}\right)$ and $13.5-25.3 \mathrm{mg} \mathrm{l}^{-1}\left(18.7 \mathrm{mg} \mathrm{l}^{-1}\right)$, respectively. These differences were significant: $\mathrm{Ca}^{2+}-t_{\text {act. }}=1.75>t_{0.05}=$ $1.65, \mathrm{Mg}^{2+}-t_{\text {act. }}=3.25>t_{0.05}=1.65$. This confirms that the concentration of $\mathrm{Ca}^{2+}$ and $\mathrm{Mg}^{2+}$ ions in water was higher at the beginning of flood, when the Nemunas run-off volume and intensity were higher. Later, in the wider part of the valley, where the flows slow down, the concentration of ions decreased. Some literature sources suggest that in the upper part of the Nemunas flooded delta the amount of sediments deposited is about twice as high as that in the lower part. However, higher amount of fine clay and silt particles are deposited in the lower part (Vaikasas, 2009). Clay minerals and humus always have negative electric charge and absorb cations from water or solutions, i.e. not only calcium, sodium, magnesium but also many heavy metal elements (Tilickis, 2005). In the Nemunas upper and lower zones and the Minija lowland the concentrations of ions varied differently. In the upper zone (1-3 sections) and the Minija lowland (8-10 sections) at the beginning of flood after the water 
had overflown into the valley the concentration of ions was the lowest and it increased with the water flow along the valley (Fig. 7). In the lower zone, when water was overflowing into the valley (4 section) the concentration of ions was the highest, in the flooded valley (5-6 sections) the ion concentration decreased and when it was outflowing from the valley (7 section) it increased.
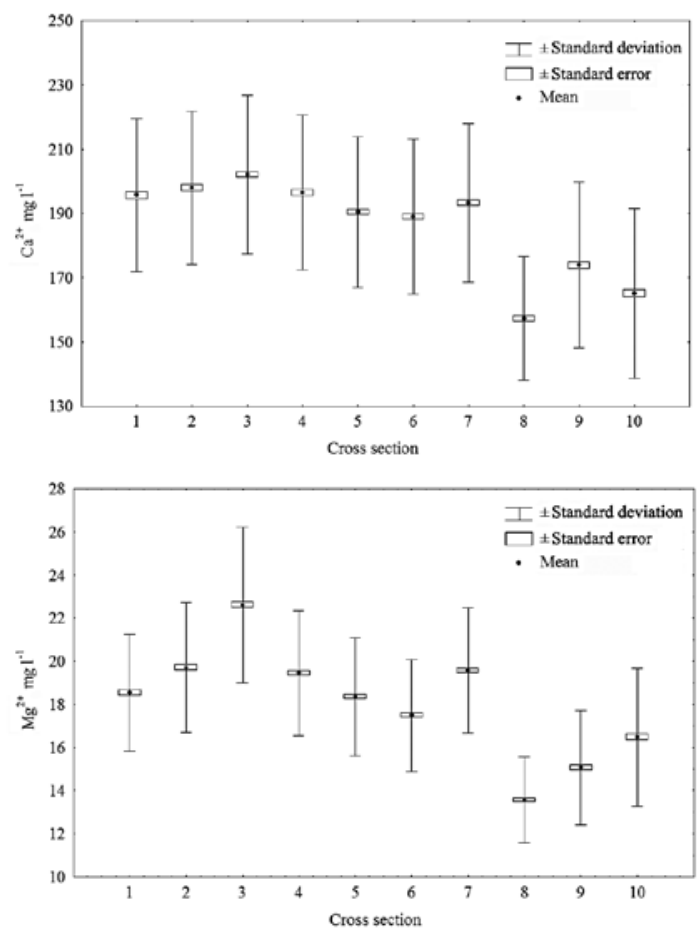

Figure 7. The change of $\mathrm{Ca}^{2+}$ and $\mathrm{Mg}^{2+}$ ion concentration in floodwater in the studied cross section

In sections 1 and 8 , the concentrations of ions reflect the amounts of substances that got into the rivers from the catchment areas. When the water is flowing along the valley $(2,3,5,6,7,9$ and 10 sections) its quality depends on the altitude of the relief, flow velocity and soil properties. With the altitude of the relief going down, the duration of flooding increases and zones of standing water are formed in which different conditions are created than in the flow zones. In the upper zones of relief, oxidative neutral and alkaline barriers are formed and in the lower zones reductive-gleyic barriers. These different geochemical barriers suspend different chemical elements (Tilickis, 2005). During sedimentation, the negatively charged ions can be removed from water in the form of sediments, especially phosphates, after they have bound to positive ions - calcium and iron (Nahlik, Mitsch, 2008). The reduction of sediment concentration is more intensive in the wider strips of the valley (Vaikasas, 2009). In the flooded valleys the flow velocity is lower, when the water flows along the valley, the flow velocity declines in the riverbed too (Rimkus, Vaikasas, 2012). Soil agrochemical properties depended on the flood flow intensity. In the flow zone, compared with the pre-land zone, the content of biogenic elements is 2.7 times and that of heavy metals 2.9 times higher (Gipiškis, 2000).

In the studied sections, the distance from the riverbed in most cases had significant $\left(F_{\text {act. }}>F_{0.05}=2.39\right)$ effect on the variation of $\mathrm{Ca}^{2+}$ and $\mathrm{Mg}^{2+}$ concentration in floodwater (Fig. 8). These differences were most apparent in the Minija lowland (8-10 sections) and the lower zone of the Nemunas lowland (4-7sections).
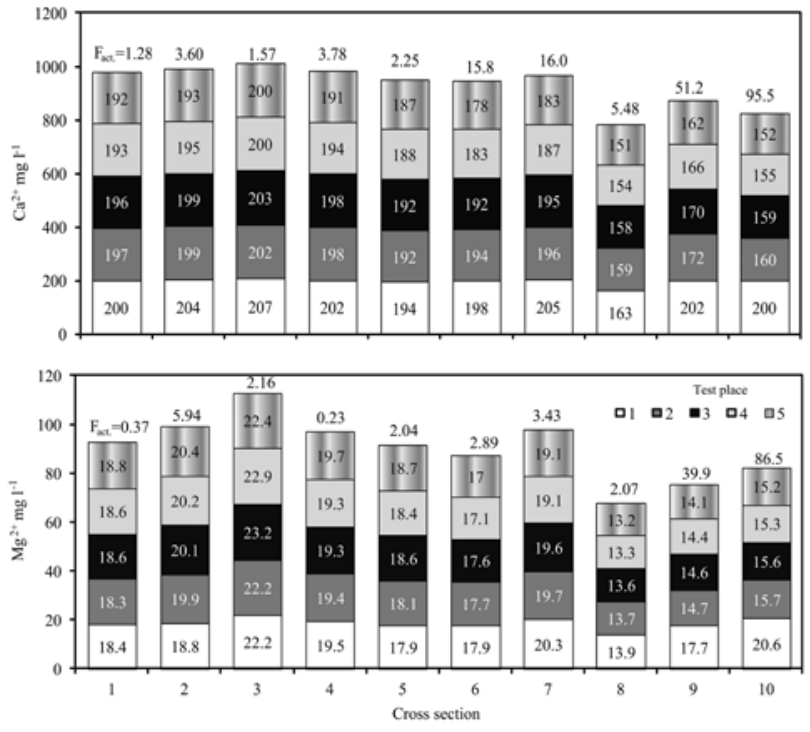

Figure 8. The concentration of $\mathrm{Ca}^{2+}$ and $\mathrm{Mg}^{2+}$ in floodwater in relation to the distance from the riverbed

The average $\mathrm{Ca}^{2+}$ concentration in the lowlands of the Nemunas (194-207 $\mathrm{mg} \mathrm{l}^{-1}$ ) and the Minija (163$202 \mathrm{mg} \mathrm{l}^{-1}$ ) in the pre-riverbed zone of the valley was the highest. With increasing distance from the riverbed the concentration of $\mathrm{Ca}^{2+}$ decreased and was the lowest 178-200 and 151-162 $\mathrm{mg} \mathrm{l}^{-1}$, respectively, in the pre-land part of the valley. The variation of $\mathrm{Mg}^{2+}$ concentration was similar to that of $\mathrm{Ca}^{2+}$. In the Minija lowland the differences of the concentrations were higher. In the Nemunas lowland the variation of $\mathrm{Mg}^{2+}$ concentration was less expressed; however, it tended to decrease with increasing distance from the riverbed. The concentration of these ions closer to the riverbed depended on the amounts carried by the river during the flood, further on with flood water moving towards pre-land part it depended on other processes. The largest amounts of metals accumulate near to the natural levee, and in low-lying areas that are frequently inundated and where large amounts of fine sediments are deposited (SchulzZunkel, Krueger, 2009). Suspended sediment deposition on grasses in flooded meadows is more intensive than in the riverbeds even when flow velocity and flow carrying capacity are high (Vaikasas, 2009). In the water flooded onto the meadows, sedimentation of clay and silt particles washed-off from fields plays a significant role in the process of its purification from biogenic matter. It has been estimated that about $40 \%$ of the fine suspended sediments can be retained and deposited in the flooded meadows of the delta (Vaikasas, Dumbrauskas, 2010). Flood flows enrich the soil with biogenic elements; bring calcium, magnesium which neutralize the acids that appear. With increasing distance from the riverbed, humification of organic matter and soil acidity reduce (Gipiškis, 2000).

When the water flows along the valley, the processes of cation exchange between water and soil takes place. With increasing $\mathrm{Ca}$ and $\mathrm{Mg}$ content in the soil, the amount of these ions also increased in water. The strongest correlation between $\mathrm{Ca}^{2+}$ and $\mathrm{Mg}^{2+}$ concentrations in the water and in soil was established in the lowest parts of the relief $(<0 \mathrm{~m})$, when the floodwater was at more than $1 \mathrm{~km}$ distance from the riverbed (Table 3). This correlation in higher parts of the relief, especially that of $\mathrm{Mg}^{2+}$ concentration was weak. 
Table 3. Relationships between $\mathrm{Ca}^{2+}\left(\mathrm{y}_{1}\right)$ and $\mathrm{Mg}^{2+}\left(\mathrm{y}_{2}\right)$ concentrations and the amount of these ions in the soil $\left(\mathrm{x}_{1}, \mathrm{x}_{2}\right)$ in different relief altitude

\begin{tabular}{ccccccccc}
\hline \multirow{2}{*}{$\begin{array}{c}\text { Altitude } \\
\mathrm{m}\end{array}$} & \multicolumn{9}{c}{$\mathrm{Ca}^{2+}$} \\
\cline { 2 - 9 } & Correlation form & $r^{2}$ & $t_{\text {act }}$ & $t_{0.05}$ & Correlation form & $r^{2}$ & $t_{\text {act }}$ & $t_{0.05}$ \\
\hline$<0$ & $\mathrm{y}_{1}=0.0057 \mathrm{x}_{1}+145.8$ & 0.82 & 7.87 & 1.75 & $\mathrm{y}_{2}=0.0033 \mathrm{x}_{2}+14.419$ & 0.43 & 3.25 & 1.75 \\
$0-1$ & $\mathrm{y}_{1}=0.0042 \mathrm{x}_{1}+158.27$ & 0.32 & 1.81 & 1.83 & $\mathrm{y}_{2}=0.0032 \mathrm{x}_{2}+15.493$ & 0.15 & 1.09 & 1.83 \\
$>1$ & $\mathrm{y}_{1}=0.0029 \mathrm{x}_{1}+1635.69$ & 0.34 & 2.62 & 1.75 & $\mathrm{y}_{2}=0.0013 \mathrm{x}_{2}+17.129$ & 0.09 & 1.14 & 1.75 \\
\hline
\end{tabular}

$r^{2}$ - determination coefficient, $t_{\text {act. }}-$ actual Student's test, $t_{0.05}-$ theoretical Student's test at significance level $\alpha=0.05 ; \mathrm{y}_{1}-\mathrm{Ca}^{2+}$ concentration in the floodwater, $\mathrm{mg} \mathrm{l}^{-1}, \mathrm{y}_{2}-\mathrm{Mg}^{2+}$ concentration in the floodwater, $\mathrm{mg} \mathrm{l}^{-1} ; \mathrm{x}_{1}-$ the amount of mobile Ca in the soil, $\mathrm{mg} \mathrm{kg}^{-1}, \mathrm{x}_{2}$ - the amount of mobile Mg in the soil, $\mathrm{mg} \mathrm{kg}^{-1}$

In the territories further away from the riverbed the water stayed longer, therefore higher concentrations of suspended sediments and biogenic matter were deposited there and at the same time their concentration in the flow declined (Adomaitis, Vaikasas, 2011).

\section{Conclusions}

1. In the floodwater of the Nemunas and Minija Rivers the concentration of $\mathrm{Ca}^{2+}$ was up to 3 times as high as annual average concentration in the river and that of $\mathrm{Mg}^{2+}-$ up to 1.6 times.

2. The concentrations of $\mathrm{Ca}^{2+}$ and $\mathrm{Mg}^{2+}$ in the floodwater are increasing, which is indicated by the positive trend of the chronological sequence of the 19872010 period

3. In the upper zone of the Nemunas lowland, the concentration of $\mathrm{Ca}^{2+} 159-248 \mathrm{mg} \mathrm{l}^{-1}$ and $\mathrm{Mg}^{2+} 14.3-29.3$ $\mathrm{mg} \mathrm{l}^{-1}$ in the floodwater was higher than that in the lower zone $-152-240$ and $13.5-25.3 \mathrm{mg} \mathrm{l}^{-1}$, respectively. The concentration of these ions in the water was higher at the beginning of flood, when the river run-off volume and intensity were higher. In the wider part of the valley where flows slow down the concentration of ions decreased.

4. The concentrations of $\mathrm{Ca}^{2+}$ and $\mathrm{Mg}^{2+}$ ions in the upper and lower zones of the Nemunas lowland and the Minija lowland varied differently. In the upper zone and in the Minija lowland, at the beginning of flood when the water outflowed onto the valley the concentration of ions was the lowest, but during the flow along the valley it increased, i.e. leached from the soil. In the lower zone when water was outflowing into the valley, ion concentration was the highest, in the flooded valley it decreased and in outflowing water from the valley it increased. At the beginning of flood, ion concentrations reflect the amounts of substances that were deposited into the rivers from the catchment areas. When the water was flowing along the valley, its quality depended on the height of the relief, flow velocity and soil properties.

5. The concentration of $\mathrm{Ca}^{2+}$ in the Nemunas (194-207 $\mathrm{mg} \mathrm{l}^{-1}$ ) and Minija (163-202 $\mathrm{mg} \mathrm{l}^{-1}$ ) lowland was the highest in the pre-riverbed part. With increasing distance from the riverbed its concentration reduced and was the lowest in the pre-land part of the valley. The variation of $\mathrm{Mg}^{2+}$ concentration was similar to that of $\mathrm{Ca}^{2+}$. The concentration of ions closer to the riverbed depended on the amounts brought by the river during flood and with floodwater outflowing towards pre-land part of the valley this concentration depended on other processes (flow velocity and distribution, soil properties, sediment suspension in meadows).
6. With water flowing along the valley, $\mathrm{Ca}$ and $\mathrm{Mg}$ concentration increased when the amount of these ions was higher in the soil. The strongest correlation $\left(r^{2}\right.$ $=0.82, t_{\text {act }}=7.87>t_{0.05}=1.75$ and $r^{2}=0.43, t_{\text {act }}=3.25$ $>t_{0.05}=1.75$ ) between $\mathrm{Ca}^{2+}$ and $\mathrm{Mg}^{2+}$ concentrations in water and the amounts of these elements in the soil was established in the lowest parts of the relief $(<0 \mathrm{~m})$, when floodwater was at more than $1 \mathrm{~km}$ distance from the riverbed.

Received 17022015

Accepted 18062015

\section{References}

Adomaitis A., Vaikasas S. 2011. Self-purification of water during the small spring flooding in the lowland of the Nemunas. Vandens ūkio inžinerija, 39 (59): 93-100 (in Lithuanian)

Agrochemical properties of Lithuanian soils and their change. 1998 / compiled by Mažvila J. Lithuanian Institute of Agriculture, 196 p. (in Lithuanian)

Banach A. M., Banach K., Visser E. J. W., Stepniewska Z., Smits A. J. M., Roelofs J. G. M., Lamers L. P. M. 2009. Effects of summer flooding on floodplain biogeochemistry in Poland; implications for increased flooding frequency. Biogeochemistrv. 92: 247-262 http://dx.doi.org/10.1007/s10533-009-9291-2

Beumer V., Van Wirdum G., Beltman B., Griffioen J., Verhoeven J. T. A. 2007. Biogeochemical consequences of winter flooding in brook vallevs. Biogeochemistrv. 86: 105-121 http://dx.doi.org/10.1007/s10533-007-9150-y

Buffam I., Laudon H., Temnerud J., Mörth C.-M., Bishop K. 2007. Landscape-scale variability of acidity and dissolved organic carbon during spring flood in boreal stream network. Journal of Geophysical Research, 112: G01022 http://dx.doi.org/10.1029/2006JG000218

Egnér H., Riehm H., Domingo W. R. 1960. Studies on the chemical analysis of the soil as the basis for evaluating the nutrient status of the soil. II. Chemical extraction methods for the determination of phosphorus and potassium. Annals Royal Agricultural College, Sweden, 26: 199-215 (in German)

Environmental Protection Agency 2001-2009. State of surface water. State of rivers. Average hydrochemical data. $<\mathrm{http}: / /$ vanduo.gamta.lt/cms/index?rubricId $=9648 \mathrm{a} 12 \mathrm{~b}-93 \mathrm{c} 8-45 \mathrm{c} 5$ bece-a81b93fce0fb $>$ [accessed 2003 2015] (in Lithuanian)

Environmental Protection Agency 2010. Nemunas river management plan. Vilnius, 333 p. <http://vanduo.gamta. lt/files/Galutinis $\% 20$ Nemuno $\% 20$ UBR $\% 20$ valdymo $\% 20$ planas.pdf $>$ [accessed 2003 2015] (in Lithuanian)

Gipiškis V. 2000. Localisation of plant nutrients and heavy metals in the lower Nemunas flood land. Vandens ūkio inžinerija, 9 (31): 77-85 (in Lithuanian)

Gipiškis V., Šlepetienė A., Arlauskienè E., Lenkšaitė E., Mališauskas A. 2007. Hydrological, physical, chemical, biological properties of the floodplain soils of the Nemunas lower reaches and relationships between them. Zemdirbyste-Agriculture, 94 (1): 115-149 (in Lithuanian) 
Jablonskis J. 2012. Runoff of the Nemunas river in winter seasons. Energetika, 58 (2): 108-116 (in Lithuanian)

Jokubauskaitė I., Šlepetienė A., Karčiauskienė D. 2014. Organic carbon and other important macronutrients in acid and limed soils. Žemès ūkio mokslai, 21 (3): 133-141 (in Lithuanian)

Katutis K. 2007. The variation of the amount of impurities in water in the lower Nemunas during flooding. ZemdirbysteAgriculture, 94 (3): 113-128 (in Lithuanian)

Loeb R., Van Daalen E., Lamers L. P. M., Roelofs J. G. M. 2007. How soil characteristics and water quality influence the biogeochemical response to flooding in riverine wetlands. Biogeochemistrv. 85: 289-302 http://dx.doi.org/10.1007/s10533-007-9135-x

Loeb R., Lamers L. P. M., Roelofs J. G. M. 2008. Effects of winter versus summer flooding and subsequent desiccation on soil chemistry in riverine hav meadow. Geoderma. 145: 84-90 http://dx.doi.org/10.1016/j.geoderma.2008.02.009

Lucassen E. C. H. E. T., Smolders A. J. P., Roelofs J. G. M. 2002. Potential sensitivity of mires to drought, acidification and mobilisation of heavy metals: the sediment $\mathrm{S} /(\mathrm{Ca}+\mathrm{Mg})$ ration as diagnostic tool. Environmental Pollution. 120: 635-646 http://dx.doi.org/10.1016/S0269-7491(02)00190-2

Lynch S. F. L., Batty L. C., Byrne P. 2014 Environmental risk of metal mining contaminated river bank sediment at redoxtransitional zone. Minerals. 4 (1): 52-73 http://dx.doi.org/10.3390/min4010052

Marcinkonis S., Booth C. A., Fullen M. A., Tripolskaja L. 2011. Soil acidity indices in East Lithuania. Communication in Soil Science and Plant Analvsis. 42: 1580-1580 http://dx.doi.org/10.1080/00103624.2011.581720

Miotliński K., Postma D., Kowalczyk A. 2012. Variable infiltration and river flooding resulting in changing groundwater quality - a case study from Central Europe. Journal of Hydrology. 414-415: 211-219 http://dx.doi.org/10.1016/j.jhydrol.2011.10.034

Moazed H., Hoseini Y., Naseri A. A., Abbasi F. 2010. Determining phosphorus adsorption isotherm in soil and its relation to soil chatacteristics. International Journal of
Soil Science. 5 (3): 131-139

http://dx.doi.org/10.3923/ijss.2010.131.139

Nahlik A., Mitsch W., 2008. The effect of river pulsing on sedimentation and nutrients in creates riparian wetlands. Journal of Environmental Quality, 37: 1634-1643 http://dx.doi.org/10.2134/jeq2007.0116

Rimkus A., Vaikasas S. 2010. Possible ways to improve sediment deposition in the Nemunas delta. Hvdrologv Research, 41 (3-4): 346-354 http://dx.doi.org/10.2166/nh.2010.118

Rimkus A., Vaikasas S. 2012. Mathematical modelling of the suspended sediment dynamics in riverbeds and valleys of Lithuanian rivers and their Deltas. Balkis N. (ed.). Water pollution, p. 105-124

Rimkus E., Kažys J., Butkutè S., Gečaitė I. 2014. Snow cover variability in Lithuania over the last 50 years and its relationship with large-scale atmospheric circulation. Boreal Environment Research, 19: 337-351

Schulz-Zunkel C., Krueger F. 2009. Trace metal dynamics in floodplain soils of the river Elbe: a review. Journal of Environmental Oualitv. 38: 1349-1362 http://dx.doi.org/10.2134/jeq2008.0299

Schulz-Zunkel C., Krueger F., Rupp H., Meissner R., Gruber B., Gerish M., Bork H.-R. 2013. Spatial and seasonal distribution of trace metals in floodplain soils. A case study with the Middle Elbe river, Germany. Geoderma, 211-212: 128-137

http://dx.doi.org/10.1016/j.geoderma.2013.07.010

Tilickis B. 2005. The change chemical composition in the Lithuanian watershed. Klaipeda, Lithuania, 200 p. (in Lithuanian)

Tumas R. 2003. Water ecology. Kaunas, Lithuania, 252 p. (in Lithuanian)

Vaikasas S. 2009. Flood dynamics and sedimentation-diffusion processes in the lowland of the river Nemunas. Vilnius, Lithuania, 248 p. (in Lithuanian)

Vaikasas S., Dumbrauskas A. 2010. Self-purification process and retention of nitrogen in floodplains of River Nemunas. Hydrology Research, 41 (3-4): 338-345 http://dx.doi.org/10.2166/nh.2010.109

\title{
Kalcio ir magnio koncentracijų kaita potvynio vandenyje Nemuno ir Minijos žemupiuose
}

\author{
K. Katutis ${ }^{1}$, A. Rudzianskaitè ${ }^{2}$ \\ ${ }^{1}$ Lietuvos Agrarinių ir miškų mokslų centro Vèžaičių filialas \\ ${ }^{2}$ Aleksandro Stulginskio universiteto Vandens išteklių inžinerijos institutas
}

\section{Santrauka}

Kalcis $(\mathrm{Ca})$ ir magnis $(\mathrm{Mg})$ yra labai svarbūs elementai dirvožemio arba vandens rūgštumui neutralizuoti, kuris yra susijęs su biotos veikla, sunkiujų metalų, fosforo ir kitų svarbių elementų judrumu. Tyrimų tikslas remiantis ilgalaikiais tyrimais įvertinti kalcio ir magnio jonų kaitos tendencijas potvynio vandenyje. Tyrimai atlikti 1987-2010 m. Nemuno (aukštutinėje Rambyno-Plaškių bei žemutinėje Girininkų-Smalkų zonose) ir Minijos žemupiuose. Abiejų upiu potvynio vandenyje $\mathrm{Ca}^{2+}$ koncentracija buvo iki 3 kartu didesnè nei vidutinè metinè koncentracija upeje, $\mathrm{Mg}^{2+}$ koncentracija - iki 1,6 karto. Nustatyta šių jonų koncentracijos potvynio vandenyje didejimo tendencija. Nemuno žemupio aukštutinèje zonoje $\mathrm{Ca}^{2+}\left(159-248 \mathrm{mg} \mathrm{l}^{-1}\right)$ ir $\mathrm{Mg}^{2+}\left(14.3-29.3 \mathrm{mg} \mathrm{l}^{-1}\right)$ koncentracija potvynio vandenyje buvo šiek tiek didesnė nei žemutinejje zonoje - atitinkamai 152-240 ir 13,5-25,3 $\mathrm{mg} \mathrm{l}^{-1}$. Šiu jonų koncentracija didèjant atstumui nuo upès vagos mažèjo ir buvo mažiausia priežemyninèje užlieto slènio dalyje. Stipriausias koreliacijos ryšys tarp $\mathrm{Ca}^{2+}\left(r^{2}=0,82, t=7,87>t_{005}=1,75\right)$ ir $\mathrm{Mg}^{2+}\left(r^{2}=0,43, t\right.$. $\left.=3,25>t_{0,05}=1,75\right)$ koncentracijų vandenyje ir šių elementų dirvožemyje nustatytas žemiausiose reljefo vietose $(<0 \mathrm{~m})$, kai potvynio vanduo nuo upès vagos buvo nutolęs daugiau kaip $1 \mathrm{~km}$. Tirtų jonų koncentracijos potvynio pradžioje atskleidžia iš baseinų ị upes patekusių medžiagų kiekį. Vandeniui tekant slèniu jo kokybẻ priklausè nuo reljefo aukščio, tėkmių greičio bei pasiskirstymo ir dirvožemio savybių.

Reikšminiai žodžiai: kalcis, magnis, pievos, potvynio vanduo, salpa. 